\title{
HUBUNGAN ANTARA KELEBIHAN BERAT BADAN DENGAN STATUS HEMOGLOBIN PADA SISWI SEKOLAH MENENGAH ATAS ATAU SEDERAJAT DI JAKARTA
}

Fitria Indriantika ${ }^{1}$ and Moesijanti Soekatri ${ }^{1}$

${ }^{1}$ Jurusan Gizi Politeknik Kesehatan DepKes Jakarta II

\section{ABSTRACT \\ THE RELATIONSHIP BETWEEN OVERWEIGHT AND HAEMOOGLOBIN (Hb) LEVEL AMONG HIGH SCHOOL FEMALE STUDENTS IN JAKARTA}

\begin{abstract}
Anemia is one of the four nutrion problem in Indonesia and most of anemia is closely associated to iron deficiency called iron deficiency anemia (IDA). Study in USA among adolesents showed that the prevalent of IDA is higher in overweight $(9.1 \%)$ than normal weight $(3.1 \%)$. Another study in Switzerland among teenage female students showed that the fat deposit in adipose tissue may decrease iron absoption. The aim of this study is to know the relationship between overweight and haemoglobin $(\mathrm{Hb})$ level using cross sectional.The female subjects were selected purposively with criteria as they were overweight $(B M I>=25)$ and registered as female students at SMAN 4, SMAN 25 and SMKN 38 in Jakarta. The overweight status were determined using Body Mass Index and finally 35 female students were filling the criteria and willing to participate. The correlation Person test was used to see the realtionship between overweight and $\mathrm{Hb}$ level.The results showed that most of the subjects $(82.9 \%)$ were categorized as obese and most of them were in the aged of 16 and 17 years (37.1\% each). About $80 \%$ of the students had a normal haemoglobin level, More than half $(88.6 \%)$ had a normal mentruation period. However, the $\mathrm{Hb}$ level less than normal $(<12 \mathrm{gr} / \mathrm{dL}$ ) were mostly found in obese subjects $(57 \%)$ rather than overweight $(43 \%)$. In $\mathrm{Hb}$ level, $80 \%$ of them had a normal haemoblobon level. The correlation test showed that there is no significant relationship between overweight and $\mathrm{Hb}$ level $(p=0.149, r=0.181)$. In needs to do the similar study with the larger group and using iron cpncentration test in blood.
\end{abstract}

Keywords: overweight, $\mathrm{Hb}$ status, high school female student

\section{PENDAHULUAN}

$\mathrm{K}$ elompok rawan gizi merupakan kelompok yang rentan terhadap masalah gizi kurang. Kelompok rawan gizi tersebut meliputi: ibu hamil, ibu menyusui, balita, dan Wanita Usia Subur (WUS). Oleh karena itu, kelompok rawan gizi ini harus menjadi perhatian utama agar terhindar dari permasalahan gizi. Remaja putri termasuk ke dalam kelompok rawan gizi kategori WUS, karena pada fase remaja terjadi berbagai macam perubahanperubahan fisik dan kematangan seksual yang jika tidak diperhatikan kebutuhan gizinya akan berdampak pada arah gizi salah, sehingga akan mempengaruhi tumbuh kembang pada remaja putri dan selanjutnya pada saat ia hamil kelak'.

Permasalahan gizi pada remaja umumnya meliputi kelebihan berat badan, anemia dan Kurang Energi Kronis (KEK) ${ }^{2}$. Berdasarkan Riskesdas tahun 2007, kelompok umur 15 tahun ke atas kelebihan berat badan pada wanita $(23,8 \%)$ terjadi lebih dominan dibandingkan pada pria $(13,9 \%)$. Hal ini menunjukkan bahwa masalah kelebihan berat badan lebih mendominasi di kalangan WUS yaitu kelompok umur 15 tahun ke atas yang termasuk di dalamnya kelompok remaja putri $^{3}$. Selain itu dalam Riskesdas 2007, melalui pemeriksaan hemoglobin didapatkan bahwa kejadian anemia pada wanita $(19,7 \%)$ lebih banyak dibanding pada pria $(13,1 \%)$. Hal ini mungkin karena jumlah zat besi yang dikeluarkan dari tubuh wanita dua kali lipat lebih banyak jika dibandingkan dengan laki-laki karena adanya menstruasi ${ }^{4}$.

Masalah anemia gizi di Indonesia lebih sering berkaitan dengan kekurangan zat besi atau biasa dikenal dengan istilah anemia gizi 
besi $(A G B)^{5}$. Penelitian di AmerikaSerikat (USA) menunjukkan prevalensi kekurangan zat besi lebih tinggi terjadi pada sampel remaja putra dan remaja putri yang memiliki kelebihan berat badan $(9,1 \%)$ dibanding dengan sampel yang memiliki berat badan normal $(3,1 \%)^{6}$.

Penelitian di Switzerland pada remaja putri, menghasilkan data bahwa penimbunan lemak di jaringan adiposa dapat menurunkan penyerapan zat besi. Sedangkan penelitian yang dilakukan pada anak-anak, menghasilkan data bahwa status besi akan rendah seiring dengan peningkatan status gizi berdasarkan $\mathrm{z}$ score ${ }^{7}$.

Anemia menjadi masalah kesehatan terbesar bagi masyarakat di dunia khususnya bagi kelompok Wanita Usia Subur (WUS). Hal ini karena pada WUS, anemia dapat menimbulkan kelelahan, badan lemah, dan penurunan produktivitas kerja. Sedangkan pada kelompok WUS golongan pelajar, anemia dapat berakibat pada kurangnya konsentrasi belajar, sehingga jika hal ini terus berlangsung maka akan berdampak pada turunnya prestasi belajar ${ }^{8}$.

Hemoglobin $(\mathrm{Hb})$ merupakan parameter yang digunakan secara luas untuk menetapkan kejadian anemia pada seseorang. Hal tersebut dapat dilakukan dengan cara menganalisa konsentrasi hemoglobin dalam sel darah merah dengan menggunakan metode yang paling umum digunakan adalah metode cyanmethemoglobin, metode ini lebih teliti, akurat dan mudah digunakan 9 .

Berdasarkan hal tersebut di atas studi ini bertujuan untuk melihat keterkaitan kelebihan berat badan dengan status hemoglobin pada siswi yang berstatus sebagai pelajar disekolah Lanjutan Tingkat Atas (SLTA ) di Jakarta. Penelitian dilakukan tiga sekolah diwilayah Jakarta Pusat yang mana lokasinya berdekatan satu dengan yang lainnya.

\section{BAHAN DAN CARA Rancangan penelitian}

Penelitian ini merupakan penelitian yang bersifat deskriptif analitik, sedangkan bila dilihat dari segi waktu, penelitian ini adalah cross sectional karena variabel independen dan dependen diukur dalam waktu yang bersamaan.

\section{Populasi dan Sampel}

Populasi penelitian ini adalah semua siswi yang kelebihan berat badan dengan nilai Indeks Massa Tubuh (IMT) $\geq 25$ dan bersekolah Sekolah Lanjutan Tingkat Atas (SLTA) diwilayah Jakarta Pusat, yaitu SMAN 4 Jakarta, SMAN 25 Jakarta dan SMKN 38 Jakarta. Jumlah populasi siswi yang kelebihan berat badan di SMAN 4 Jakarta ada sebanyak 28 orang, di SMAN 25 Jakarta ada sebanyak 20 orang dan di SMKN 38 Jakarta ada sebanyak 25 orang, sehingga total populasi dalam penelitian ini ada sebanyak 73 orang. Pengambilan sampel atau subjek penelitian dilakukan dengan metode purposive sampling dengan kriteria (1) siswi yang berstatus sebagai pelajar di salah satu dari 3 sekolah terpilih, (2) sudah mendapat menstruasi, (3) memiliki kelebihan berat badan (IMT $\geq 25$ ),(4) bersedia menjadi subjek penelitian dan (5) tidak cacat fisik agar tidak mengganggu proses wawancara dan pengukuran antropometri.Jumlah sampel yang memenuhi kriteria didapat 35 orang siswi

\section{Jenis data dan cara pengumpulan}

Data primer yang diambil meliputi primer dan sekunder. Primer meliputi data identitas, data antropometri (berat badan dan tinggi badan), kadar hemoglobin dengan menggunakan alat hemocue metode cyanmethemoglobin, sedanngkan data sekunder meliputi gambaran umum sekolah. Pengumpulan data primer dilakukan dengan menggunakan kuesioner mencakup nama siswi, umur, kelas / semester, asal sekolah, domisili, dan status menstruasi. Status menstruasi meliputi teratur atau tidak teratur.

Data antropometri meliputi data berat badan dalam kilogram $(\mathrm{kg})$ dengan alat timbangan Tanita dengan kapasitas $136 \mathrm{~kg}$ dan tingkat keakuratan $0,1 \mathrm{~kg}$, sedangkan tinggi badan $(\mathrm{m})$ menggunakan microtoise 
dengan kapasitas $200 \mathrm{~cm}$ dan keakuratan $0,1 \mathrm{~cm}$. Dari data ini kemudiann dapat dihitung Indeks Masa Tubuh(IMT) nya. Indeks Masa Tubuh selain digunakan untuk screening subjek, juga dilakukan untuk mengkategorikan "overweight" dan Obese".

Pengklasifikasian kelebihan berat badan didasarkan pada perhitungan Indeks Massa Tubuh (IMT) pada subjek yang diteliti. Subjek dikategorikan overweight jika memiliki IMT $\geq 25,0$ - 27,0. Sedangkan subjek dikategorikan obesitas jika memiliki IMT > 27,0. Pada sampel, terdapat 17.1 persen yang termasuk kategori overweight dan sebagian besar 82.9 persen termasuk kategori obesitas

Data biokimia didapatkan dengan bantuan tenaga analis kesehatan dari Southeast Asian Ministers of Education Organization Tropical Medicine and Public Health (SEAMEO TROPMED).melalui penentuan kadar (hemoglobin) $\mathrm{Hb}$ dengan menggunakan metode cyanmethemoglobin dengan alat hemocue. Untuk data sekunder didapat dengan cara mencatat data yang relevan menggunakan dokumen yang ada di SMAN 4 Jakarta, SMAN 25 Jakarta dan SMKN 38 Jakarta.

\section{Analisa Data}

Dilakukan dengan mendiskripsikan data menggunakan tabel satu arah meliputi data independent yaitu kelebihan berat badan dan variabel dependent yakni status hemoglobin. Selain itu data penyebaran jumlah subjek di tiap sekolah, penyebaran umur, penyebaran kelebihan berat badan, status $\mathrm{Hb}$, Tabel dua arah juga menjelaskan secara diskriptif antara status menstruasi dengan kelebiohan berat badan, status menstruasi dengan kadar $\mathrm{Hb}$, dan status $\mathrm{Hb}$ dengan kelebihan berat badan. Test korelasi Person dilakukan untuk melihat hubungan antara kadar $\mathrm{Hb}$ dan kelebihan berat badan.

\section{Keterbatasan Penelitian}

Karena keterbatasan waktu dan dana, penelitian ini tidak memeriksa kadar zat besi dalam darah dan terbatas pada subjek pelajar di 3 sekolah dengan jumlah sampel yang secara relatif sedikit.

\section{HASIL}

Karakteristik sampel

Jumlah subjek penelitian tiap sekolah berbeda beda. Dari 35 sampel, 51 persen (18 orang) bersekolah di SMAN 4 Jakarta, 29 persen (10 orang) ada di SMAN 25 Jakarta, dan terkecil 20 persen (7 orang) berada di SMAKN 38 Jakarta. Dari segi umur, terbanyak pada usia 16 dan 17 tahun sama besar yaitu masing masing sebanyak 37,1 persen (13 orang) sisanya berusia 17 tahun ada sejujmlah 25.8 persen ( 9 orang). Dari data menstruasi, tercatat 88,6 persen (31 orang) siswi mendapatkan haid secara teratur selama 3 bulan terakhir dan sisanya 11,4 persen (4 orang) merasa haidnya tidak teratur. Untuk tingkat kelebihan berat badan dikategorikan menjadi 2 kategori, yakni "berat badan lebih" (overweight) dan "obesitas". Dari mereka yang obese ternyata sebagian besar mendapakan haid yang tidak teratur seperti digambarkan pada tabel dibawah ini.

\section{Hubungan antara 2 variabel}

Tabel 1

Penyebaran Status Menstruasi Berdasarkan Tingkat Kelebihan Berat Badan Pada Siswi SMA atau Sederajat di Jakarta

\begin{tabular}{ccccccc}
\hline \multirow{2}{*}{ Status Menstruasi } & \multicolumn{2}{c}{ Overweight } & \multicolumn{2}{c}{ Obesitas } & \multicolumn{2}{c}{ Jumlah } \\
\cline { 2 - 7 } & $\mathrm{n}$ & $\%$ & $\mathrm{n}$ & $\%$ & $\mathrm{n}$ & $\%$ \\
\hline Teratur & 6 & 19,0 & 25 & 81,0 & 31 & 100,0 \\
Tidak Teratur & 0 & 0 & 4 & 100,0 & 4 & 100,0 \\
\hline
\end{tabular}


Kadar Haemoglobin siswi yang dijadikan sampel menunjukkan bahwa sebagian besar mempunyai kadar $\mathrm{Hb}$ yang normal. Untuk melihat status menstruasi berdasarkan status hemoglobin Tabel 2 menunjukkan bahwa mereka yang mempunyai $\mathrm{Hb}$ normal lebih banyak yang mendapatkan haid tidak teratur daripada yang teratur.

Tabel 2

Penyebaran Status Menstruasi Berdasarkan Status Hemoglobin

\begin{tabular}{lcccccc}
\hline \multirow{2}{*}{ Status Menstruasi } & \multicolumn{2}{c}{ Normal } & \multicolumn{2}{c}{ Anemia } & \multicolumn{2}{c}{ Jumlah } \\
\cline { 2 - 7 } & $\mathrm{n}$ & $\%$ & $\mathrm{n}$ & $\%$ & $\mathrm{n}$ & $\%$ \\
\hline Teratur & 24 & 77,0 & 7 & 23,0 & 31 & 100,0 \\
Tidak Teratur & 4 & 100,0 & 0 & 0 & 4 & 100,0 \\
\hline
\end{tabular}

Hubungan antara status hemoglobin dan tingkat kelebihan berat badan menunjukkan bahwa mereka yang obesitas ternyata lebih banyak yang mempunyai status $\mathrm{Hb}$ yang normal sedangkan mereka yang overweight lebih banyak yang anemia, Lihat Tabel 3 berikut ini.

Tabel 3

Penyebaran Status Hemoglobin Berdasarkan Tingkat Kelebihan Berat Badan

\begin{tabular}{lcccccc}
\hline \multirow{2}{*}{ Status Hemoglobin } & \multicolumn{2}{c}{ Overweight } & \multicolumn{2}{c}{ Obesitas } & \multicolumn{2}{c}{ Jumlah } \\
\cline { 2 - 7 } & $\mathrm{n}$ & $\%$ & $\mathrm{n}$ & $\%$ & $\mathrm{n}$ & $\%$ \\
\hline Normal & 3 & 11,0 & 25 & 89,0 & 28 & 100,0 \\
Anemia & 3 & 43,0 & 4 & 57,0 & 7 & 100,0 \\
\hline
\end{tabular}

Berdasarkan pada ketiga tabel 1, 2 dan 3 menunjukkan bahwa siswi yang obese ternyata lebih banyak yang tidak teratur menstruasinya tetapi banyak yang normal $\mathrm{Hb}$ nya dan dari yang mempunyai $\mathrm{Hb}$ normal mempunyai lebih banyak yang mendapatkan menstruasi yang tidak teratur.

\section{Test korelasi Person}

Analisa ini digunakan untuk mengetahui keeratan adanya hubungan antara kelebihan berat badan dengan status hemoglobin.
Analisa korelasi pearson yang digunakan mengarah pada one tail, karena berdasarkan hipotesis yang digunakan menunjukkan adanya pembatasan pada variabel independen, yakni hanya dibatasi pada subjek yang memiliki kelebihan berat badan.

Hal ini menunjukkan bahwa hubungan antara kedua variabel tidak signifikan $(p>0.05)$ dengan kata lain menaiknya berat badan tidak terbukti dapat menurunkan haemoglobin darah.

Tabel 4

Analisis Korelasi Kelebihan Berat Badan dengan Status Hemoglobin

\begin{tabular}{llcc}
\hline & & IMT & Status $\mathrm{Hb}$ \\
\hline \multirow{3}{*}{ IMT } & Korelasi Pearson & 1 & $.181^{*}$ \\
& Sig (1-tailed) & & .149 \\
& $\mathrm{~N}$ & 35 & 35 \\
\hline \multirow{2}{*}{ Status Hb } & Korelasi Pearson & $.181^{*}$ & 1 \\
& Sig (1-tailed) & .149 & \\
\hline
\end{tabular}




\begin{tabular}{lll}
$\mathrm{N}$ & 35 & 35 \\
\hline
\end{tabular}

\section{BAHASAN}

Untuk hasil keteraturan mendapat menstruasi atau haid pada siswi sekolah lanjutan tingkat atas (SLTA)., menunjukkan bahwa pada penelitian Purwanti (2006) tentang Hubungan Presentasi Lemak Tubuh, Aktivitas Fisik dan Frekuensi Olah Raga dengan Siklus Menstruasi Pada Siswi SMAN 9 Semarang tahun 2006 presentase subjek yang memiliki status menstruasi tidak teratur adalah 21,3 persen sedangkan dalam penelitian ini jumlah yang tidak teratur ternyata lebih sedikit yaitu sebanyak 11,4 persen.

Pada penelitian sejenis yang dilakukan oleh Hasye (2008) tentang Hubungan Antara Ukuran Tubuh dengan Umur Menarche Pada Siswi Sekolah Dasar dan Sekolah Menengah Pertama di Yayasan Penglima Besar Jendral Sudirman Jakarta Timur pada tahun 2008, memperlihatkan bahwa data prevalensi subjek yang obesitas adalah sebanyak 31 persen. Jika dilakukan perbandingan dengan studi ini, maka prevalensi obesitas dalam penelitian Hasye (2008) lebih sedikit dari penelitian yang dilakukan oleh Penulis $(82,9 \%)$

Pada penelitian yang dilakukan oleh Karina (2008) tentang Hubungan Kejadian Anemia dengan Pola Konsumsi, Sosial Ekonomi, Pengetahuan Anemia, Pengetahuan Suplemen Zat Besi, Konsumsi Suplemen Zat Besi, IMT serta Lamanya Haid Remaja Putri Kelas 1 di SMAN 1 Kota Bogor pada tahun 2008, menunjukkan bahwa prevalensi subjek yang anemia sebanyak 15,2 persen. Jika dilakukan perbandingan, maka besar presentase subjek penelitian yang anemia pada penelitian Karina (2008) lebih sedikit dari penelitian ini (20\%).

Perbedaan hasil antara studi ini dengan studi yang lain meskipun sama sama dilakukan pada siswi SLTP dan SLTA adalah karena adanya faktor psikologis yang sedikit banyak memberi andil dalam memberikan informasi dalam studi ini. Menurut Anwar (2006) ternyata obesitas ini sering berdampak pada kurang baik pada perkembangan sosial dan psikososial. Yang bersangkutan lebih banyak menyendiri, depresi, dan rendah gairah hidup. Keadaan yang kurang menguntungkan terjadi karena pada obesitas beresiko tinggi terhadap penyaki degeneratif bahkan kematian ${ }^{2}$. Karena itu informasi mengenai keteraturan menstruasi dalam 3 bulan terakhir mungkin underestimate.

Berdasarkan teori bahwa pada orang yang memiliki kelebihan berat badan, terjadi penimbunan lemak yang berlebihan, sehingga dapat berakumulasi di hati. Keadaan ini bermula dari peningkatan kadar asam lemak bebas sebagai katabolisme lemak di dalam darah. Asam lemak bebas dengan jumlah yang meningkat akan diambil oleh hati dan produksi VLDL (Very Low Density Lipoprotein) tidak dapat mengikuti kecepatan aliran masuk asam lemak bebas sehingga terjadi penimbunan triasilgliserol yang akan menyebabkan timbunan lemak pada hati. Akumulasi keadaan ini dapat memicu pembentukan peroksida lipid yang pada akhirnya akan mempengaruhi proses metabolisme besi sehingga akan terjadi radikal bebas ${ }^{10}$. Hal ini menyebabkan sintesis $\mathrm{Hb}$ tidak dapat berjalan dengan sempurna. Pada tahap akhir, hemoglobin menurun jumlahnya (hipokromik) dan eritrosit mengecil atau lebih dikenal mikrositik. Sehingga dapat terjadilah anemia ${ }^{27}$. Dalam studi ini hubungan antara kelebihan berat badan tidak ada huibungan yang signifikan dengan kadar $\mathrm{Hb}$, kemungkinan hal ini disebabkan jumah sampel yang terlalu sedikit dalam penelitian ini sehingga tidak cukup membuktikan adanya korelasi.

\section{SIMPULAN}


Studi ini mencoba menghubungkan antara kelebihan berat badan dengan status haemoglobin. Keduanya dilakukan dengan pengukuran dengan cara dan standar yang umum dilakukan dalam suatu penelitian. Pengukuran tinggi badan dan berat badan dilakukan dengan alat dengan presisi yang baik $(0,1 \mathrm{~cm}$ untuk tinggi badan dan $0,1 \mathrm{~kg}$ untuk berat badan). Pengukuran $\mathrm{Hb}$, dilakukan dengan bantuan tenaga analis kesehatan yang terlatih dengan alatg hemocue yang langsung dapat dibaca langsung ditempat sehingga darah tidak perlu disimpan dalam lemari es dan tidak diperlukan waktu untuk tranportasi dan analisa. Diduga karena jumlah sampel yang tidak cukup banyak maka tidak cukup bukti untuk melihat hubungan antara kelebihan berat badan dengan status haemoglobin sisiwi SLTA di Jakarta. Faktor lain ikut memberi kontribusi pada status Hemoglobin saat studi dilaksanakan. Karena studi ini tidak membedakan saat menstruasi atau tidak saat pengambilan darah maka kemungkinan saat kunjungan mempengaruhi status $\mathrm{Hb}$ siswi SLTA. Saat menstruasi adalah saat dimana seorang wanita akan kehilangan darah dan besi dan kalau diperiksa $\mathrm{Hb}$ saat itu kemungkinan $\mathrm{Hb}$ berada dibawah 12 gram/dL menjadi besar. Faktor lain yang tidak dipertimbangkan dalam studi ini adalah stress. Pada saat studi dilaksanakan siswi sudah selesai dengan ujian semester dan sedang melaksanakan tanding olah raga antar kelas, sehingga saat studi dilaksanakan faktor stress tidak ada sehingga kemungkinan menstruasinya teratur dapat saja terjadi.

\section{REKOMENDASI}

Penelitian yang hampir sama dengan jumlah sampel yang lebih besar dan diambil secara random serta melibatkan sekolah yang mewakili semua wilayah di Jakarta perlu dilakukan untuk melihat kaitan bahaya kelebihan berat badan dengan dimensi salah satu masalah gizi yang utama yaitu anemia.
Bila benar, maka dalam pendidikan gizi kelebihan berat badan tidak menjamin tidak adanya defisiensi tapi perlu diwaspadai adanya anemia dan defisiensi zat gizi yang lain.

\section{RUJUKAN}

1. Roberts, Bonnie $S$ Worthington. Nutrition Throughout The Life Cycle. Singapore : Mc Graw-Hill, 2000.

2. Mahdin Anwar, Husaini. Gizi Seimbang Untuk Remaja Dan Wanita Usia Subur. Dalam Hidup Sehat Gizi Seimbang Dalam Siklus Kehidupan Manusia. Jakarta: PT Primamedia Pustaka, 2006.

3. Hasil Riset Kesehatan Dasar. Jakarta: Badan Penelitian dan Pengembangan Kesehatan, 2008.

4. Khomsan, Ali. Pangan dan Gizi Untuk Kesehatan. Jakarta : PT Raja Grafindo Persada, 2003

5. Almatsier, Sunita. Prinsip Dasar IImu Gizi. Jakarta: PT Gramedia Pustaka Utama, 2004

6. J, Nead Karen et al. Overweight Children and Adolescence: A Risk Group For Iron Deficiency. 2004. Avalaible from: URL: HYPERLINK http:www.pediatric.com

7. M, Zimmermann B et al. Adiposity in women and children from transition countries predicts decreased iron absorption, iron deficiency and reduced response to iron fortification. 2008 April 22. Avalaible from : URL : HYPERLINK http:www.nature.com/ijo/journal/v32/n7l abs/ijo200843a.html

8. Departemen Gizi dan Kesehatan masyarakat FKMUI. Gizi dan Kesehatan Masyarakat. Jakarta : PT Raja Grafindo, 2007

9. Supariasa, dkk. Penilaian Status Gizi. Jakarta: Penerbit Buku Kedokteran EGC, 2002

10. Mayes, Peter A. Biokimia Harper. Jakarta: Penerbit Buku Kedokteran EGC, 2003. 